\title{
A Preliminary Study on the Coupling Mechanism of Ideological and Political Theory Course Practice Teaching and Theory Teaching*
}

\author{
Pumin Cai, Ting Chang \\ School of Marxism, Tiangong University, Tianjin, China \\ Email: caipm2003@126.com
}

How to cite this paper: Cai, P. M., \& Chang, T. (2020). A Preliminary Study on the Coupling Mechanism of Ideological and Political Theory Course Practice Teaching and Theory Teaching. Creative Education, 11, 1402-1406.

https://doi.org/10.4236/ce.2020.118102

Received: July 23, 2020

Accepted: August 23, 2020

Published: August 26, 2020

Copyright ( 2020 by author(s) and Scientific Research Publishing Inc. This work is licensed under the Creative Commons Attribution International License (CC BY 4.0).

http://creativecommons.org/licenses/by/4.0/

\begin{abstract}
In ideological and political course teaching, how to deal with the relationship between theory teaching and practice teaching has always been an important issue that teachers and administrators urgently need to face. It is necessary to establish a coupling mechanism of theory teaching leading practice teaching, practice teaching serving theory teaching, and realizing the positive interaction between practice teaching and theory teaching. In this way, the contradiction between theoretical teaching and practical teaching can be effectively resolved and the attraction and effectiveness of ideological and political course can be continuously improved.
\end{abstract}

\section{Keywords}

Ideological and Political Theory Course, Practice Teaching, Classroom Theory Teaching, Effectiveness

\section{Introduction}

According to Basic Requirements of Ideological and Political Theory Teaching in Colleges and Universities in the New Era of The Ministry of Education, college ideological and political theory course (hereinafter referred to as ideological and political course) is divided into two parts: theoretical teaching and practical teaching. In addition to theoretical teaching in the classroom, "two credits are deducted from the existing credits of undergraduate ideological and political theory course and one credit of junior college, ideological and political theory courses will be deducted to carry out practical teaching of undergraduate and *The phased achievement of the promotion project of ideological and political theory course teaching reform in universities in Tianjin "Research on Practical Teaching Reform of Ideological and Political Theory Course". 
junior colleges' ideological and political theory courses." (Ministry of Education in China, 2018) This is the first time for the Ministry of Education to stipulate the status of ideological and political course practice teaching in the form of documents, which makes the ideological and political course practice teaching have a legal status. Under such circumstances, it is of great practical significance to correctly deal with the relationship between theoretical teaching and practical teaching and establish the coupling mechanism of benign interaction between practical teaching and theoretical teaching for improving the effectiveness of ideological and political course teaching.

\section{Taking Classroom Theory Teaching as the Leading Factor}

Classroom theory teaching is the main channel of ideological and political course teaching in universities. In general, all educational and teaching activities have the basic goal of imparting knowledge to teachers and students mastering knowledge. And all of these basically can be completed in the classroom, which can be seen as a basic law that education and teaching must follow at all times and in all countries. Leave classroom teaching, basically already did not belong to current university type. In another sense, the common feature of school education today is that it takes classroom teaching as the main channel. Of course, education and teaching can also be carried out by non-classroom teaching, but the status of classroom teaching as the main channel cannot be removed. Specific to the ideological and political education in colleges and universities teaching, the goal is to impart positive energy to students and cultivate students' grasp of scientific world outlook, values and outlook on life. Such a course with both knowledge and politics cannot refuse classroom teaching at all. We must take classroom teaching as the main channel and enhance the teaching effect of ideological and political courses by strengthening classroom teaching.

Of course, we emphasize the use of the main channel of classroom teaching and are not opposed to the reform of classroom teaching. Monotonous indoctrination can't improve the teaching effect, but in the process of reform, we must adhere to the basic principle of "content is king". Any form of reform can't ignore the basic content of ideological and political course at any time; the form of teaching is to serve the content. Without the content, the form has no value. Ideological and political course teaching reform should start from the nature, characteristics and objects of ideological and political course itself, adhering to the ideological and political work, teaching and educating, and student growth of these three laws to carry out teaching reform.

\section{Taking Practical Teaching as a Supplement}

In 2004, the CPC Central Committee and the State Council pointed out in the Opinions on Further Strengthening and Improving Ideological and Political Education for College Students that "social practice is an important part of ideological and political education for college students. It is necessary to estab- 
lish a social practice security system for college students and explore a long-term mechanism of practical education for college students". (The CPC Central Committee and the State Council, 2004) In 2005, Publicity Department of the CPC Central Committee and Ministry of Education pointed out in Opinions on Further Strengthening and Improving Ideological and Political Theory Courses in Institutions of Higher Learning that "all courses of political theory courses in institutions of higher learning should strengthen the practice link, establish and perfect the guarantee mechanism of practical teaching, and explore the long-term mechanism of practical teaching". (Publicity Department of the CPC Central Committee \& Ministry of Education, 2005) It can be seen that carrying out practical teaching of ideological and political course is not only the requirement of implementing the spirit of the Central Committee, but also the breakthrough of improving the effectiveness and pertinence of ideological and political course teaching.

The accurate orientation of practical teaching of ideological and political course: practical teaching is an effective supplement of theoretical teaching and an extension, expansion and deepening of theoretical teaching. This requires that the practice teaching should be combined with the ideological and political course teaching content, with the classroom theory teaching, and realize the organic unity with the classroom theory teaching. Only in this way can practice teaching achieve healthy and sustainable development and get due results. For this reason, the CPC Central Committee and the State Council clearly pointed out in Opinions on Strengthening and Improving Ideological and Political Work in Colleges and Universities under The New Situation that "we should strengthen social practice education, increase the proportion of practical teaching, and organize teachers and students to participate in social practice activities". (The CPC Central Committee and the State Council, 2017)

Practice teaching strengthens the basic characteristic of the practicality of Ideological and political theory education in concept, and highlights the characteristics of life and reality of Ideological and political theory education. Practice teaching combines the theoretical knowledge of ideological and political theory with the rich and colorful social life, especially the daily life of students. It uses ideological and political theory to guide students to observe social reality, analyze social problems, and think about the trend of social development. It confirms ideological and political theory with perceptual, visible and tangible vivid reality. Through the organic combination of theory and practice, young students can personally feel the power of the truth of ideological and political theory, and feel the value and role of ideological and political theory. And then improve the attractiveness and appeal of ideological and political course, and improve the sense of acquisition and happiness of ideological and political theory course for college students.

From the perspective of the teaching objectives of ideological and political course in colleges and universities, it is only one of the objectives to guide young students to establish a correct world outlook, outlook on life and values. What's 
more important is to cultivate their ability to analyze and solve problems by using theory. While practical teaching deepens the understanding of theoretical knowledge, through carrying out various forms of practical activities, on the basis of improving their theoretical knowledge attainment, it also exercises and cultivates various abilities and maximizes the goal of ideological and political education.

\section{The Positive Interaction between Practical Teaching and Classroom Theory Teaching}

For a long time, pure classroom theory teaching is the only teaching mode of ideological and political course, and the teaching method is single. Teachers play a leading role in the classroom, unilaterally instill theory into students, students' participation in classroom theory teaching activities is low, teachers' teaching and students' learning become two parallel lines. In addition, the teaching content is divorced from the reality of society and students, and the course lacks certain appeal and persuasion, which makes it difficult to arouse students' resonance and arouse students' enthusiasm in learning the course. In this case, we need to "adhere to the combination of political theory education and social practice, and not only attach importance to classroom education, but also pay attention to guiding college students to go deep into the society, understand the society and serve the society." (The CPC Central Committee and the State Council, 2004) In addition to classroom theoretical teaching, practical teaching should be supplemented. The classroom theoretical teaching and practice teaching should be organically combined, and flexible and diverse teaching forms should be adopted. We should make students participate in it, visit the scene in person, change from supporting role to leading role, from passive learning to active integration, and actively explore the problems in the practical teaching content. Practice teaching, with the advantages of broadening the field of vision and integrating theory with practice, is a teaching link and teaching form loved by college students, which is conducive to enhancing the teaching effect of Ideological and political course and improving the effectiveness of ideological and political course teaching.

It should also be noted that, there has been a bad tendency according to the current practical situation of practical teaching operation. The one-sided emphasis on practical teaching reduces the importance of theoretical teaching in class consciously or unconsciously. Practice teaching has been carried out with great vigor and excitement, but it has forgotten that the theme of practice teaching is the practice teaching of ideological and political course, which deviates from the theme of ideological and political course. The result weakens the theory and orientation of ideological and political course and confuses the difference between practical teaching of ideological and political course and that of other courses.

Although practice teaching lays particular stress on practice, the purpose of practice teaching is to better understand theory and to cooperate with classroom 
theory teaching. We cannot make any distinction between the primary and the secondary cause a presumptuous guest usurps the host's role. That means we can't treat practice teaching as the leading role, practice teaching will be separated from the core of ideological and political theory course. Therefore, the content of practical teaching of ideological and political course should focus on Marxist theory and ideological and political education related content, such as the basic theory of Marxism, China's national conditions and the history and achievements of revolutionary construction and reform, education in patriotic ideology and morality, education in socialist democracy and the legal system, theory and practice of socialism with Chinese characteristics must be included. In this way, it can embody the essential feature of the extension of practical teaching to theoretical teaching in class, thus contributing to the realization of practical teaching objectives.

\section{Conclusion}

In a word, as an important part of ideological and political course teaching, theoretical teaching and practical teaching are equally important and cannot be neglected. By strengthening the high consistency of theoretical teaching and practical teaching objectives, the complementary integration of teaching functions, the deep integration of teaching content, the organic coordination of teaching forms, the scientific construction of the coupling mechanism of theoretical teaching and practical teaching of ideological and political course, the theoretical teaching and practical teaching can resonate with each other on the way to improve the effectiveness of ideological and political course teaching.

\section{Conflicts of Interest}

The authors declare no conflicts of interest regarding the publication of this paper.

\section{References}

Ministry of Education in China (2018). The Basic Requirements of Ideological and Political Theory Teaching in Colleges and Universities in the New Era. In the China Education Daily 2018-4-14 (1).

Publicity Department of the CPC Central Committee \& Ministry of Education (2005). Opinions on Further Strengthening and Improving Ideological and Political Theory Courses in Institutions of Higher Learning. In the People's Daily 2005-3-3 (1).

The CPC Central Committee and the State Council (2004). Opinions on Further Strengthening and Improving Ideological and Political Education for College Students. In the People's Daily 2004-10-15 (1).

The CPC Central Committee and the State Council (2017). Opinions on Strengthening and Improving Ideological and Political Work in Colleges and Universities under New Situation. In the People's Daily 2017-3-1 (1). 